\title{
PENDAMPINGAN KEGIATAN PROGRAM KEMITRAAN MASYARAKAT DENGAN PEMBUATAN BAHAN AJAR APLIKASI VIDEO SCRIBE PADA GURU DI SD MUHAMMDIYAH PANDES BANTUL
}

\author{
Suraya $^{1}$, Erfanti Fatkhiyah ${ }^{2}$,Hadi Prasetyo Suseno ${ }^{3}$ \\ ${ }^{1,2}$ Teknik Informatika, ${ }^{3}$ Teknik Lingkungan \\ Institut Sains \& Teknologi AKPRIND Yogyakarta \\ J1. Kalisahak 28 Yogyakarta \\ ${ }^{1}$ suraya@akprind.ac.id, ${ }^{2}$ fanti@ akprind.ac.id, ${ }^{3}$ hadi@ akprind.ac.id
}

\begin{abstract}
Abstrak
Di era informasi ini, masih ada guru yang belum menganggap penting penggunaan teknologi informasi dalam proses pembelajaran. Sebenarnya pemanfaatan teknologi informasi dalam bidang pembelajaran dapat menunjang proses pembelajaran. Dengan teknologi informasi diharapkan dapat meningkatkan efektivitas dan kualitas pembelajaran dan yang lebih penting adalah untuk meningkatkan penguasaan teknologi informasi baik bagi guru mau pun siswa sebagai bekal hidup di era teknologi yang terus berubah dan berkembang. Sebagai upaya untuk meningkatkan kompetensi guru dalam penguasaan teknologi informasi, pendampingan kegiatan yang terkait dengan teknologi informasi harus selalu diberikan. Salah satu pendampingan kegiatan untuk para guru di SD Muhammadiyah Pandes Bantul adalah pengembangan bahan ajar dengan video scribe. Hasil kuesioner yang diberikan sebelum adanya pendampingan, 95\% guru belum menggunakan bahan ajar berbasis teknologi informasi dan $80 \%$ tidak mengetahui adanya aplikasi yang dapat dengan mudah digunakan untuk mengembangkan bahan ajar. Jawaban 20\% yang pernah menggunakan bahan ajar berbasis TIK, para guru hanya menggunakan Microsoft Power Point dan 2 guru pernah mengikuti pelatihan membuat bahan ajar dengan aplikasi Lectora. Hasil akhir pelatihan, berdasar kuesioner yang diberikan di akhir pelatihan menunjukkan, semua guru yang mengikuti pelatihan menjawab penggunaan video scribe sangat mudah dan hasil yang ditampilkan sangat menarik
\end{abstract}

Kata kunci : guru, teknologi informasi, bahan ajar

\section{PENDAHULUAN}

Dalam dunia pendidikan, keberadaan peran dan fungsi guru merupakan salah satu faktor yang sangat signifikan. Guru merupakan bagian terpenting dalam proses belajar mengajar, baik di jalur pendidikan formal, informal maupun nonformal. Oleh sebab itu, dalam setiap upaya peningkatan kualitas pendidikan di tanah air, guru tidak dapat dilepaskan dari berbagai hal yang berkaitan dengan eksistensi mereka.

Di era informasi ini, tanpa adanya kemauan untuk mengerti, menggunakan, dan mengakses bidang yang relevan dengan keilmuannya maka fungsi guru sebagai fasilitator perkembangan ilmu akan tereduksi yang lama-lama bisa jadi hilang, sehingga yang ada hanya guru yang miskin informasi. Masih ada guru yang beranggapan tidak menggunakan komputer dan TIK dalam proses pembelajaran bukan hal mengganggu jalannnya pelajaran,.. Pemanfaatan media TIK dalam bidang pendidikan, dapat menunjang pembelajaran yang merupakan suatu keharusan, bukan hanya untuk meningkatkan efektivitas dan kualitas 
pembelajaran, tetapi yang lebih penting adalah untuk meningkatkan penguasaan TIK baik bagi guru mau pun siswa sebagai bekal hidup di era teknologi yang terus berubah dan berkembang. Dalam konteks pembelajaran, pemanfaatan dan pemberdayaan media TIK, termasuk teknologi multimedia, dapat meningkatkan efektivitas dan efisiensi pembelajaran, yang diharapkan dapat memberikan kepuasan siswa.

Dalam proses belajar mengajar, salah satu faktor yang dapat mempengaruhi minat belajar adalah media yang digunakan dalam proses tersebut. Media pembelajaran merupakan alat bantu yang sangat diperlukan oleh para guru dalam untuk menyampaikan materi pelajaran. Di era teknologi informasi dan komunikasi (TIK) saat ini, guru juga harus dapat menyesuaikan dalam penggunaan media pembelajaran. Dengan menggunakan media pembelajaran berbasis TIK diharapkan akan membuat media menjadi semakin menarik dan mudah untuk dipahami. Penggunaan media pembelajaran akan berpengaruh terhadap kegiatan peserta didik selama proses belajar mengajar. Media pembelajaran bisa dibuat secara manual maupun dengan bantuan software atau aplikasi yang ada di internet.

Menurut Undang-Undang No 14 tahun 2005 tentang Guru dan Dosen, guru sebagai pekerjaan profesional harus memiliki prinsip-prinsip profesional seperti tercantum pada pasal 7 ayat 1, yaitu: Profesi guru dan dosen merupakan bidang pekerjaan khusus yang memerlukan prinsip-prinsip profesional sebagai berikut: (a) memiliki bakat, minat, panggilan jiwa dan idealisme; (b) memiliki kualifikasi pendidikan dan latar belakang pendidikan sesuai dengan bidang tugasnya; (c) memiliki kompetensi yang diperlukan sesuai dengan bidang tugasnya; (d) mematuhi kode etik profesi; (e) memiliki hak dan kewajiban dalam melaksanakan tugas; (f) memperoleh penghasilan yang ditentukan sesuai dengan prestasi kerjanya; (g) memiliki kesempatan untuk mengembangkan profesinya secara berkelanjutan; (h) memperoleh perlindungan hukum dalam melaksanakan tugas profesionalnya; dan (i) memiliki organisasi profesi yang berbadan hukum. Berdasarkan Peraturan Pemerintah (PP) Nomor 18 Tahun 2007 tentang Guru, dinyatakan bahwasanya kompetensi yang harus dimiliki oleh Guru meliputi kompetensi pedagogik, kompetensi kepribadian, kompetensi sosial, dan kompetensi profesional yang diperoleh melalui pendidikan profesi. [1]

Pembuatan media berbasis TIK tidak harus menggunakan aplikasi yang komplek tetapi para guru dapat memilih atau menggunakan aplikasi yang mudah dalam pembuatan bahan ajar tetapi menghasilkan luaran/ media pembelajaran yang menarik. Salah satu software yang dapat digunakan adalah Sparkol Video scribe. Sparkol video scribe merupakan salah satu software yang dapat membantu dalam pembelajaran matematika. Dengan media Sparkol video scribe ini kita dapat merancang dan membuat presentasi lebih menarik dan profesional. Di dalam aplikasi ini terdapat fitur-fitur yang menarik seperti gambar, jenis tulisan, model huruf, warna, musik yang dapat dipilih sesuai keinginan yang nanti akan membuat isi materi semakin menarik. Proses pembuatan bahan ajar digital dapat menggunakan aplikasi yang khusus digunakan untuk mengembangkan bahan ajar. Dengan aplikasi yang khusus ini, proses pembuatan bahan ajar dapat dilakukan dengan mudah dan para guru diharapkan tidak mengalami kesulitan. Salah satu aplikasi yang dapat digunakan dalam pengembangan bahan ajar adalah dengan menggunakan sparkol video scribe.

Hasil penelusuran pustaka, diperoleh sudah banyak sekolahan yang menyelenggarakan pelatihan bagi guru dalam menggunakan TIK, diantaranya :

[2] Dalam makalahnya memaparkan hasil pelatihan video scribe pada guru SMK Tembarak Temanggung. Peran guru di era digital saat ini tidak hanya berperan sebagai pendidik tetapi juga sebagai penggerak dalam menggunakan teknologi informasi. Perkembangan teknologi informasi yang berkembang cepat harus dapat diikuti para guru dengan menggunakan teknologi informasi dalam proses belajar mengajar. Salah satu bentuk penggunaan teknologi informasi dapat diimplementasikan dalam bentuk bahan ajar. Dengan adanya bahan ajar berbasis digital ini, proses pembelajaran dapat dikemas lebih menarik dengan menambahkan materi yang menggunakan multimedia seperti animasi, gambar dan video.

[3] Pengembangan media ANVIS berbasis Sparkol video scribe diharapkan dapat bermanfaat antara lain: (a) Bagi Siswa: mendapatkan media edukasi yang menarik, 
efektif, dan fleksibel sebagai pendukung kegiatan pembelajaran dan sebagai media yang dapat digunakan untuk membantu pemahaman siswa tentang materi persiapan kemerdekaan RI. (b) Bagi guru: sebagai media alternatif yang efektif dan fleksibel untuk digunakan dan juga memudahkan guru untuk menarik perhatian siswa dalam mengajarkan dan pengenalan sejarah khususnya tentang persiapan kemerdekaan RI. (c) Bagi sekolah: memberikan alternatif media pembelajaran yang dapat digunakan oleh sekolah guna meningkatkan kualitas pembelajaran di sekolah tersebut. Hasil yang dikembangkan adalah pemanfaatan teknologi sebagai salah satu sumber belajar yang dikemas dalam sebuah media pembelajaran yang memuat materi tentang

sejarah persiapan kemerdekaan RI untuk siswa kelas VI SD dengan judul "pengembangan Media Pembelajaran Video Animasi Berbasis Sparkol video scribe tentang persiapan kemerdekaan RI untuk SD Kelas V".

Video pembelajaran merupakan salah satu jenis media yang mengutamakan kekuatan suara dan gambar. Sejarah matematika merupakan mata kuliah pilihan dimana jenis materi dalam mata kuliah ini bersifat faktual, sehingga dalam proses pembelajarannya dosen lebih mengedepankan metode ceramah, presentasi dan diskusi. Untuk lebih mengefektifkan proses perkuliahan maka akan disusun suatu inovasi pembelajaran yaitu dengan mengembangkan video pembelajaran berbantuan aplikasi sparkol video scribe. Tujuan utama dari penelitian ini adalah mengembangkan video pembelajaran berbantuan aplikasi sparkol video scribe pada mata kuliah sejarah matematika serta mendeskripsikan langkah pembelajaran yang mendukungnya. Penelitian ini merupakan penelitian pengembangan yang meliputi tahap concept, design, collecting materials, assembly, test drive dan distribution. [4]

[5] Media pembelajaran sangat diperlukan dalam proses pembelajaran selain siswa mudah menerima dan memahami ilmu dan materi pelajaran yang disampaikan oleh guru, siswa juga terlibat aktif dalam proses pembelajaran serta dapat mengatasi kejenuhan siswa saat proses pembelajaran berlangsung. Penggunaan media pembelajaran oleh guru memiliki variasi yang berbeda-beda karena terdapat banyak jenis media pembelajaran yang dikembangkan dalam proses belajar mengajar di dalam kelas. Penggunaan variasi media pembelajaran di kelas dapat memudahkan siswa dalam memahami pelajaran dan membuat mereka tertarik dengan materi yang disampaikan, seperti pada saat penulis menerapkan media pembelajaran audio visual yaitu video mengenai materi ekonomi, siswa pada saat proses pembelajaran terlihat aktif dan antusias. Beberapa siswa terlihat bersemangat dan mudah untuk memahami materi pelajaran melalui video yang ditampilkan. Hal tersebut memberikan dampak positif pada hasil belajarnya terlihat dari hasil tes dari soal yang diberikan oleh penulis setelah menerapkan media pembelajaran video.

[6] Media Pembelajaran sebagai wadah untuk membuat proses belajar dan mengajar lebih efektif membutuhkan suatu pembaruan dan kepekaan seorang pengajar dengan kebutuhan peserta didik atau siswa nya. Kedua hal ini mampu memproduksi suatu inovasi yang akan membuat para siswa lebih tertarik mempelajari materi yang sedang guru tampilkan di kelas. Pada pelaksanaan Pelatihan pemanfaatan Sparkol Video scribe ini, dapat disimpulkan bahwa penggunaan media pembelajaran yang merupakan salah satu motivasi ketertarikan peserta didik sangat dibutuhkan tidak hanya oleh dewan guru namun juga harus adanya dukungan sekolah dan pemangku keputusan untuk memediasi penggunaan media Sparkol Video Scribe di semua mata pelajaran.

\section{METODE}

\subsection{Khalayak Sasaran Khalayak}

Sasaran pengabdian masyarakat ini adalah para guru SD Muhammadiyah Pandes, Wonokromo, Pandes, Bantul. Jumlah peserta yang mengikuti pendampingan sebanyak 27. Peserta pelatihan disamping dari guru SD Muhammadiyah Pandes, jug diikuti perwakilan dari guru SD Muhammadiyah yang ada di kecamatan Pleret. 


\subsection{Metode Kegiatan}

Kegiatan program pengabdian kepada masyarakat (PPM), diawali dengan kuesioner untuk mengetahui sejauh mana para guru sudah mendapatkan pelatihan yang terkait dengan pembuatan bahan ajar berbasis TIK terutama penggunaan video scribe. Pendataan ini digunakan agar proses pendampingan tidak duplikasi materi yang pernah didapat guru.

Di akhir pelaksanaan pelatihan, juga dilakukan pemberian kuesioner yang bertujuan untuk mengetahui sejauh mana para guru memahami materi videoscribe, baik dari sisi penggunaan aplikasi tersebut dalam proses pembelajaran ataupun dari sisi kemudahan dari aplikasi tersebut. Langkah kegiatan PPM ada pada ada pada gambar 1

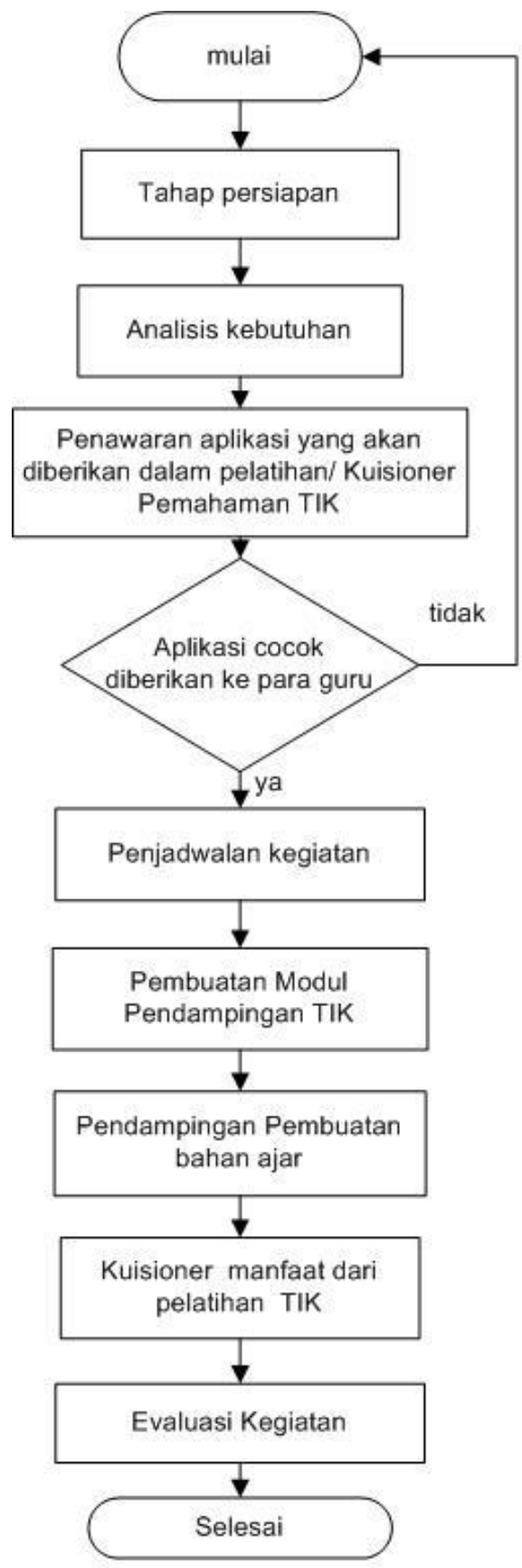

Gambar 1 Langkah-langkah dalam kegiatan PkM 


\section{HASIL DAN PEMBAHASAN}

\subsection{Hasil Kuesioner}

\subsubsection{Kuesioner sebelum kegiatan PkM}

Sebelum pelaksanaan kegiatan PPM, tim melakukan identifikasi untuk mengetahui sejauh mana para guru sudah memahami atau pernah mengikuti pelatihan pembuatan bahan ajar dengan menggunakan TIK atau khususnya menggunakan aplikasi video scribe. Identifikasi dilakukan dengan melakukan diskusi dengan kepala sekolah dan memberikan kuesioner kepada guru. Hasil kuesioner diataranya disajikan dalam grafik 1-4

1. Sudah berapa lama Bapak/Ibu mengajar ?

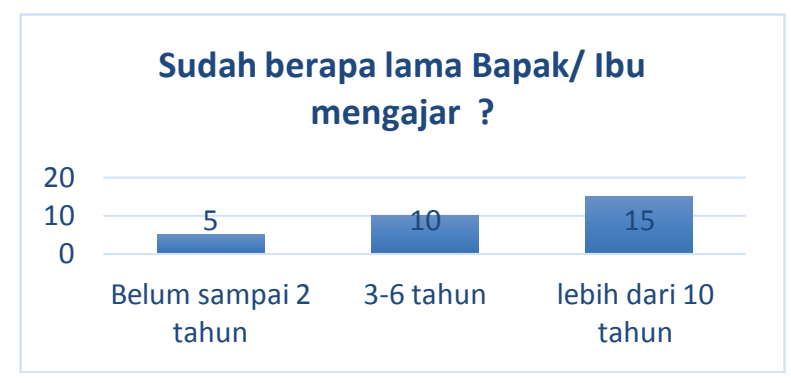

Grafik 1. Hasil kuisioner dengan pertanyaan berapa lama guru sudah mengajar

2. Apakah Bapak/ Ibu pernah mengajar dengan menggunakan media pembelajaran?

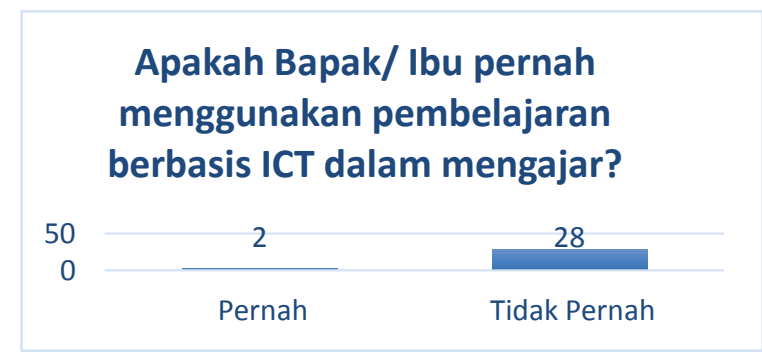

Grafik 2. Hasil kuisioner dengan pertanyaan apakah pernah menggunakan ICT dalam proses mengajar

3. Apakah Bapak/ Ibu pernah mengikuti pelatihan atau kegiatan sejenisnya tentang penggunaan media pembelajaran berbasis ICT?

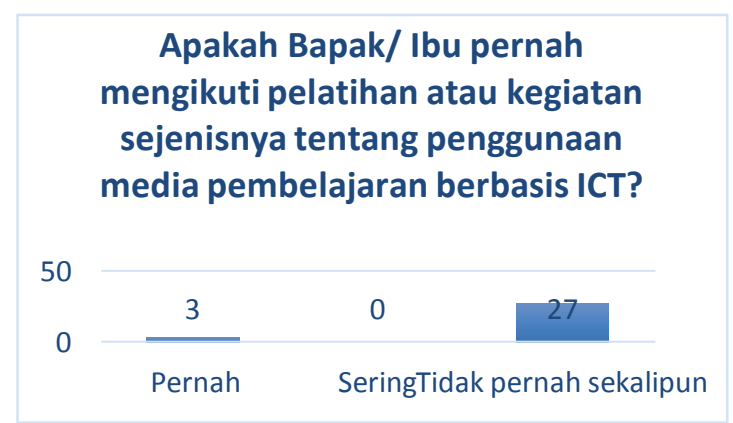

Grafik 3. Hasil kuisioner dengan pertanyaan

apakah pernah mengikuti pelatihan ICT yang digunakan dlam proses pembelajaran 
4. Apakah Bapak/ Ibu pernah menggunakan pembelajaran berbasis ICT dalam mengajar?

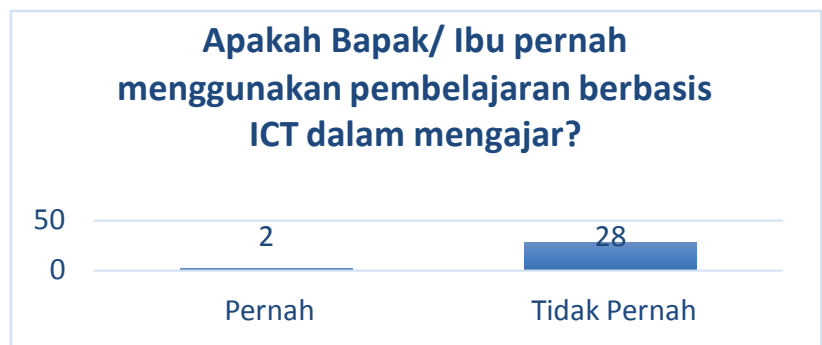

Grafik 4. Hasil kuisioner dengan pertanyaan

apakah pernah pernah menggunakan ICT dalam proses mengajar

Kesimpulan dari hasil kuesioner, para guru yang diberikan pelatihan pembuatan bahan ajar dengan video scribe, 93\% guru belum pernah mengikuti pelatihan membuat bahan ajar berbasis TIK, dan 7\% pernah mengikuti pelatihan membuat bahan ajar dengan menggunakan Microsoft Power Poin. Dari kuesioner tersebut pelatihan membuat bahan ajar dengan video scribe belum pernah diikuti peserta sehingga pelatihan diharapkan memberikan manfaat dan pemahaman para guru untuk membuat bahan ajar dengan video scribe.

\subsubsection{Kuesioner setelah kegiatan PkM}

Setelah mengikuti pelatihan peserta diberikan kuesioner yang berisi pertanyaan mengenai manfaat pelatihan dan penggunaan video scribe. Hasil kuesioner diantaranya disajikan dalam grafik 5-7

1. Video scribe mudah untuk digunakan

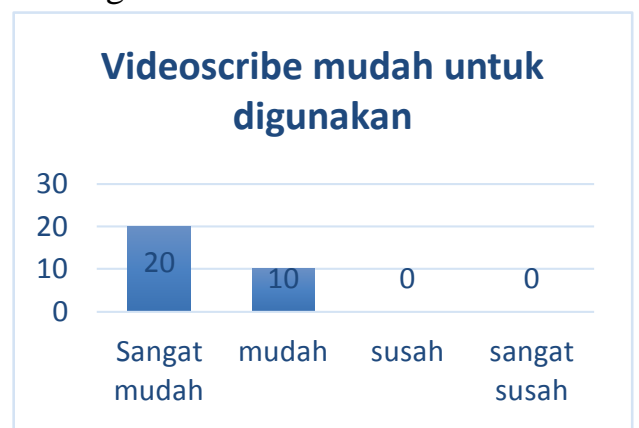

Grafik 5. Hasil kuisioner dengan pertanyaan apakah video scribe mudah digunakan

2. Saya sudah memahami video scribe

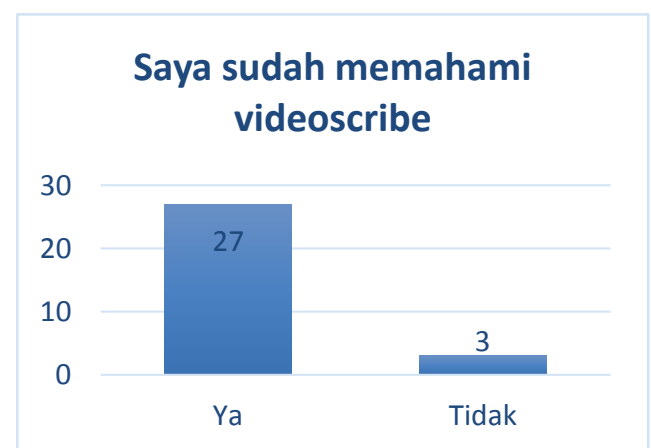

Grafik 6. Hasil kuisioner dengan pertanyaan apakah suda memhami video scribe 
3. Penggunaan media ajar berbasis ICT sangat membantu kejelasan materi pelajaran

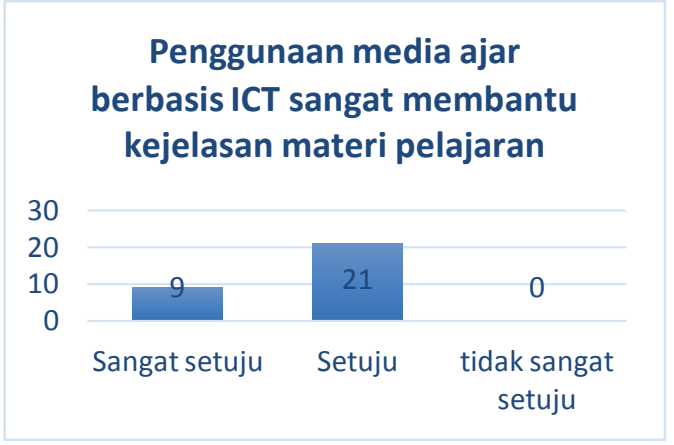

Grafik 7. Hasil kuisioner dengan pertanyaan

apakah video scribe sangat membantu kejelasan materi pelajaran

\subsection{Hasil Pelatihan dan Pendampingan}

Pelaksanaan pelatihan diikuti 30 guru dan didampingi mahasiswa yang membantu proses pelatihan. Pelaksanaan pelatihan diawali dengan contoh hasil videoscribe yang digunakan untuk bahan ajar atau promosi dan dilanjutkan dengan pemaparan materi dan dilanjutkan praktik secara langsung. Gambar 2-4 merupakan proses pelaksanaan pelatihan yang sudah dilakukan.
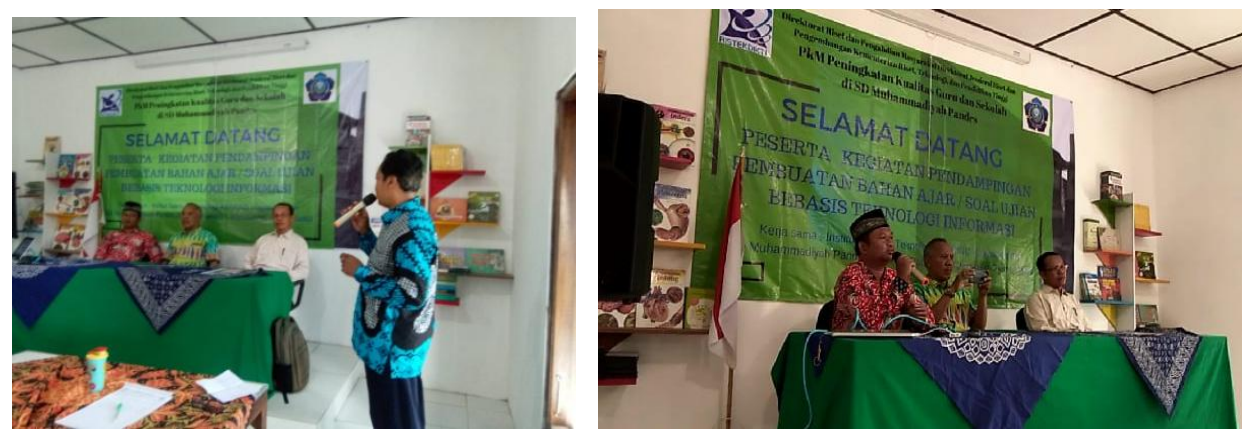

Gambar 2 Pembukaan Acara dan Sambutan Kepala Sekolah
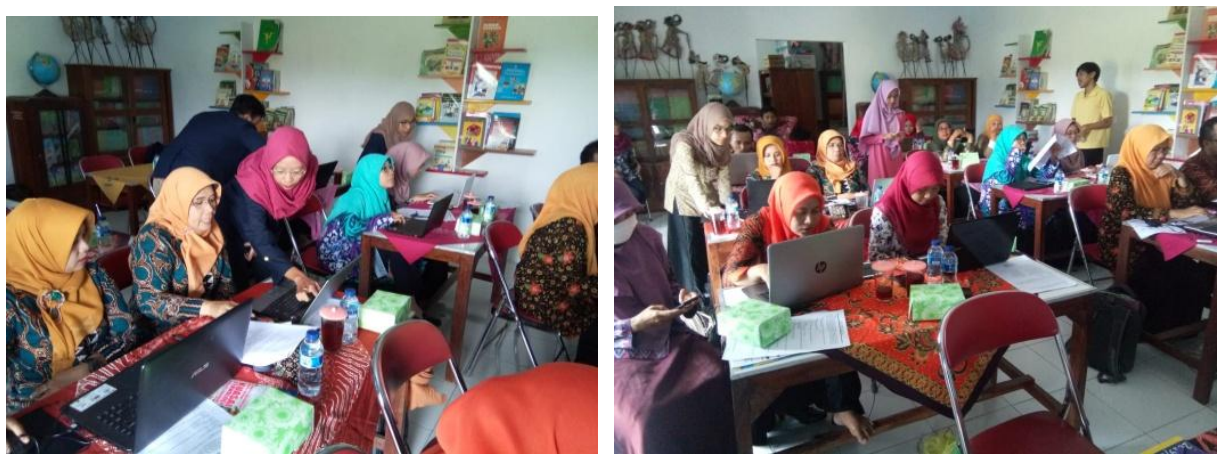

Gambar 3 Suasana Pelaksanaan Pelatihan dan Pendampingan Kegiatan
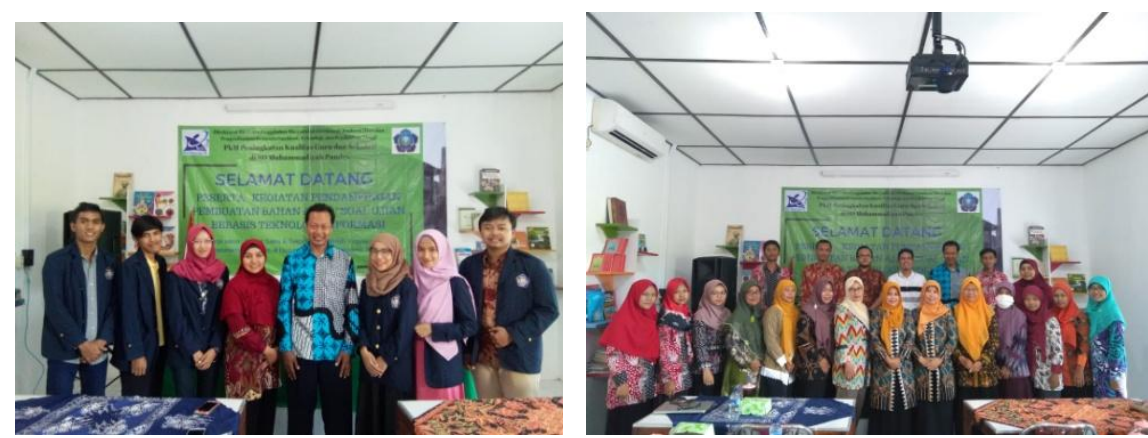

Gambar 4 Tim Asisten mahasiswa dan Para guru peserta pelatihan 
Teknis pelaksanaan kegiatan PPM ini, para langsung mempraktikkan dengan membuat bahan ajar dari masing-masing mata pelajaran dan di akhir pelatihan, masingmasing guru memaparkan hasil pelatihan. Gambar 5-6 . contoh hasil pelatihan pembuatan bahan ajar dengan video scribe.
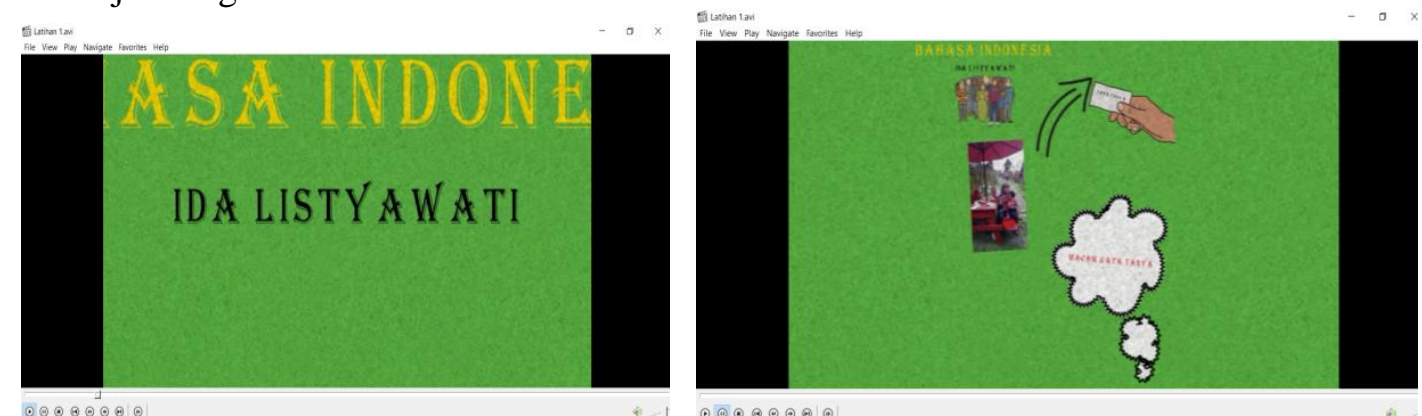

Gambar 5 Hasil Pelatihan dan pendampingan
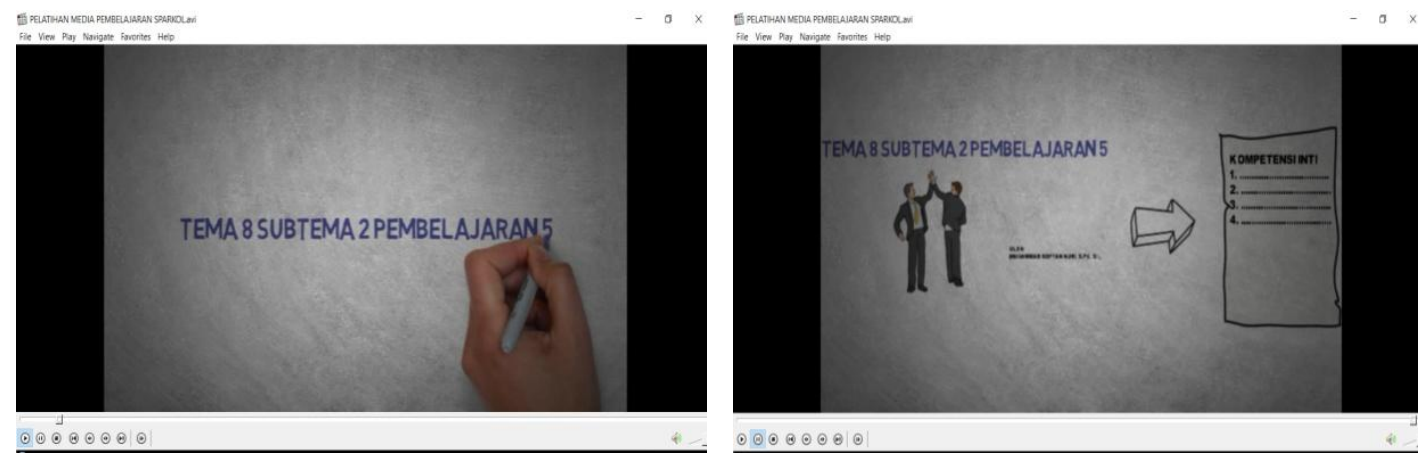

Gambar 6 Hasil Pelatihan dan pendampingan

\section{KESIMPULAN}

Dari pelaksanaan program pengabdian kepada masyarakat melalui skema Program Kemitraan Masyarakat Kemristekdikti dapat ditarik beberapa kesimpulan, yakni :

- Kegiatan PkM yang diberikan para guru dengan video scribe ini merupakan salah satu rangkaian kegiatan PkM yang bermitra dengan SD Muhammadiyah Pandes. Rangkaian kegiatan yang lain diantaranya pelatihan bahan ajar dengan aplikasi yang lain, membuat soal berbasis TIK, pelatihan arsi berbasis digital serta kegiatan bertema lingkungan hidup

- Pelaksanaan kegiatan yang bertemakan TIK bertujuan untuk memberikan pengetahuan kepada para guru, proses pembuatan bahan ajar berbasis TIK dapat dilakukan dengan mudah

- Kemudahan dalam pengembangan ini karena adanya aplikasi yang tidak memerlukan pengembangan yang rumit. Proses pembuatan dilakukan dengan memilih animasi atau gambar yang diinginkan.

- Aplikasi video scribe dapat menjadi salah satu referensi bagi para guru untuk mengembangkan bahan ajar berbasis TIK

- Hasil pelatihan menghasilkan bahan ajar sederhana yang diharapkan dikembangkan secara keseluruhan

- Berdasar hasil kuesioner, aplikasi video scribe mudah digunakan dan menghasilkan luaran yang menarik. 


\section{SARAN}

Keberlanjutan dari kegiatan ini semestinya menjadi komitmen semua pihak termasuk kepala sekolah agar mendorong para guru untuk mengembangkan bahan ajar. Agar para guru dapat mengembangkan bahan ajar, para guru perlu mendapatkan alternatif-alternatif lain dalam menggunakan aplikasi. Dengan adanya alternatif aplikasi yang diberikan, guru dapat memilih aplikasi yang dirasa mudah dan menarik dalam pembuatan bahan ajar.

\section{UCAPAN TERIMA KASIH}

Penulis mengucapkan terima kasih kepada Direktorat Riset dan Pengabdian pada Masyarakat Direktorat Jenderal Riset dan Pengembangan Kementerian Riset, Teknologi dan Pendidikan Tinggi yang telah memberi dukungan dana untuk kegiatan Pengabdian kepada masyarakat pada skema Program Kemitraan Masyarakat (PKM) tahun pendanaan 2019.

\section{DAFTAR PUSTAKA}

[1] Munir, KERANGKA KOMPETENSI TIK Bagi Guru, Bandung : Penerbit Alfabeta, Bandung, 2014.

[2] M. Sholeh, "PENDAMPINGAN PENGEMBANGAN BAHAN AJAR DENGAN VIDEOSCRIBE PADA GURU SMK TEMBARAK TEMANGGUNG," Jurnal Abdimas BSI, vol. 2, no. 1, pp. 1-9, 2019.

[3] M. Q. Silmi, "PENGEMBANGAN MEDIA PEMBELAJARAN VIDEO ANIMASI BERBASIS SPARKOL VIDEOSCRIBE TENTANG PERSIAPAN KEMERDEKAAN RI SD KELAS V," JPGSD, vol. 6, no. 4, pp. 486-495, 2018.

[4] A. S. Pamungkas and A. S. Pamungkas, "VIDEO PEMBELAJARAN BERBASIS SPARKOL VIDEOSCRIBE: INOVASI PADA PERKULIAHAN SEJARAH MATEMATIKA," Prima: Jurnal Pendidikan Matematika, vol. 2, no. 2, pp. 27 - 135, 2018.

[5] Dellyardianzah, "PENGGUNAAN MEDIA PEMBELAJARAN BERBASIS VIDEO SCRIBE UNTUK MENINGKATKAN HASIL BELAJAR SISWA PADA MATA PELAJARAN EKONOMI," Jurnal Pendidikan dan Pembelajaran, vol. 10, no. 6, pp. 1$10,2017$.

[6] T. Athena, "PEMANFAATAN MEDIA SPARKOL VIDEO SCRIBE DI SEKOLAH DASAR," ELPEDUAEM , vol. 4, no. 4, pp. 19-21, 2018. 